\title{
On the Curriculum Setting Management of College English ESP Elective Courses Based on Demand Theory
}

\author{
Guoting Qian ${ }^{1, a}$, Ming Wang ${ }^{2, b,{ }^{*}}$, Jie Wei ${ }^{1, c}$, Yiyan Shu ${ }^{1, d}$, Yihang Ding ${ }^{1, e}$, \\ Zhengyu Ren ${ }^{1, f}$, Ruocheng Wang ${ }^{2}$, Bo Yan ${ }^{3}$ \\ ${ }^{1}$ School of Foreign Languages, Wuhan University of Technology, Wuhan 430070, China \\ ${ }^{2}$ School of Mechanical and Electrical Engineering, Wuhan University of Technology, Wuhan \\ 430070,China \\ ${ }^{3}$ School of Information Engineering, Wuhan University of Technology, Wuhan 430070,China \\ *email: wmanthea@sina.com
}

\begin{abstract}
Nowadays, English elective course setting is not consistent with the actual needs of the students, which results that students can not receive general English education to solve professional problems. This article aims to study the Curriculum Setting Management of college English ESP elective courses based on demand theory and thus provide a better learning management environment.
\end{abstract}

Key words: college English education management; ESP; demand theory; elective courses

\section{Introduction}

\subsection{ESP Theory}

Recently, ESP teaching in China has become a heated debate in higher education. The Former Minister of Education Secretary Zhang Yaoxue in 2002 made it clear that colleges should encourage practical English teaching to improve the comprehensive ability of college students. At the same time, college students in modern time have higher requirements to English and are prone to study higher level of professional English. Learning English should adapt to the reality. With the help of several English learning classroom models, they put forward a new idea.

\subsection{Demand Theory}

The developnt of ESP has experienced five stages (Li Hongbin: 2007), and the demand analysis first appeared in the third stage of the development of ESP Teaching -- the stage of the target scene. Professors Xia Jimei, Kong Xianhui (1999), Chen Liping (2000), Wang Haixiao (2004) and Shu dingfang (2004), studied need analysis from the curriculum design, angle of syllabus design and the types of need analysis( Xu Wei, 2012:131).

In weatern, Hutchinson and Waters (1987) divided need analysis into target needs and learning needs. The target needs means that learners can successfully apply the knowledge and skills in the target scene, and the learning needs to be done in order to learn the knowledge and skills.

In domestic, Shu Dingfang divided needs analysis into social needs and personal needs. If you do not understand the needs of society, so that students cannot really adapt to the needs of the community. Individual needs include objective needs and subjective needs. Individual needs analysis is consist with requirements of Chinese traditional education -- teach students in accordance with their aptitude. Therefore, in the ESP course setting must meet the needs of learners. Shooting the arrow at the target.

\section{Curriculum Setting Management of College English ESP Elective Courses}

\subsection{Empirical Research}

1. Respondent: college students throughout the country, teachers of English major in school of foreign languages, Wuhan University of Technology.

2. Scope of survey: 200 e-questionnaires were sent to more than one colleges, more than one majors, mainly non-English majors. 105 were recycled. And the interviewees were mainly our school teachers.

3. Survey methods: Questionnaire survey; interview. 
4. Inspection process: the interview, paper questionnaires and e-questionnaires were conducted at the same time. Through extensive data analysis, scientific conclusion was made.

5. Conclusion: Richards(1984) thought that "language courses must agree with the purpose of learners studying languages in the real world", that is to say, the curriculum should satisfy the demands, achieve the aims, only in this way can we maximize the effect of reform. According to the survey, the roles of teachers and students have changed a lot. Teachers tend to be guides, organizers of the courses, while students would like to be the main body of the courses rather than requiring knowledge passively. An interactive, game-type teaching mode is demanded by the majority of the teachers and students.

\subsection{Curriculum Setting Management Based on Demand Theory}

The teaching mode of ESP elective courses of college English based on demand theory can be divided into several modules. They are teacher module, student module, communication and interaction module, display module and evaluation module. The sketch of the teaching model is shown in Figure 1.

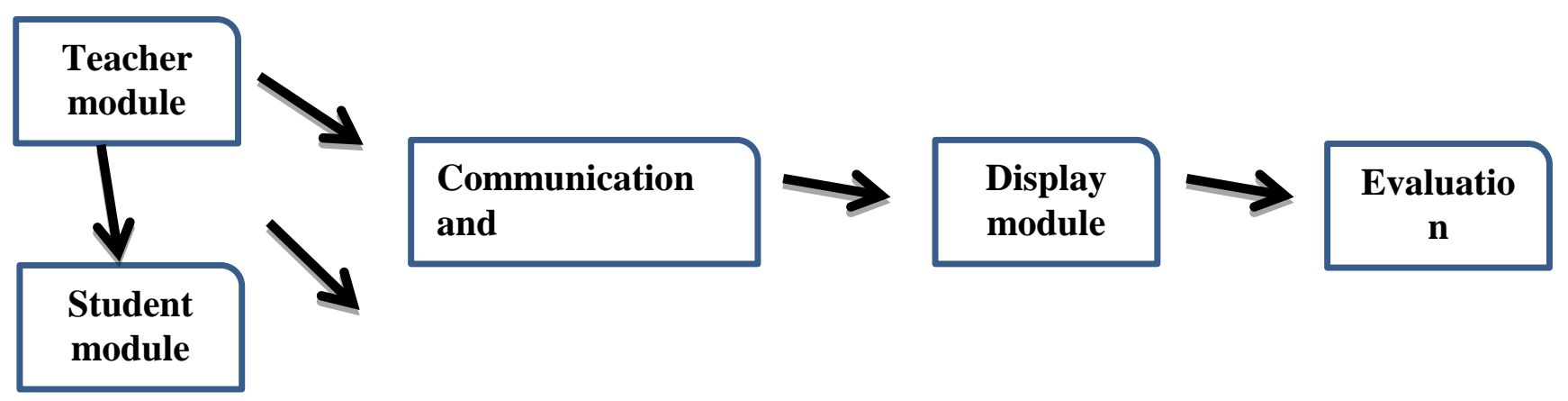

\section{Fig.1 The Curriculum Setting Management of College English ESP Elective Courses Based on Demand Theory}

1. Teacher module: In the module, teachers still play a role in class, but it represents higher standards to teachers (Wang Youliang, 2008). In class, teachers shouldn't impart knowledge all the time, but pay more attention to the design of course material and time allocation. Teachers should stimulate students' interest in learning and guide them to master professional English and expertise.

2. Student module: Strevens (1998: 1 - 13 ) came up with four distinguishing features of teaching ESP. One of them is that the curriculum must meet the specific needs of learners. Therefore, in the class students should be dominant. The setting of student module breaks the rigid teacher-centered system and stimulates students' interest in learning. Meanwhile, for students, full participation is beneficial to leave profound impression, and firmly grasp the knowledge touched on in class.

3. Communication and interaction module: It is a link in which students have a broad and in-depth exchange of views and practice on what they have learned in class. It is also an important part aiming to implementing students' dominant position. There are various ways of implementing activities, such as simulating the model of Professional academic conference and recruit.

4. Display module: display module is based on the communication and interaction module. In the module, students can state their result of discussion or display it by PPT.

5. Evaluation module: The module involves two parts, which are students' evaluation and teachers' evaluation. Students can evaluate classmates' presentation from the contents and the effect of the display. The module is beneficial to cultivate critical thinking. And teachers' comments, which facilitate the final evaluation deeper and more authoritative, can be used as a supplement to students' evaluation.

Teacher module involves the first and last part of ESP elective courses of College English, in which teachers state aims and demands of this class and make their comment on students' presentation in the class. Student module, which is the second part of ESP elective courses of College English, involves Communication and Interaction module and Display module. Meanwhile, all activities implementing in Communication and Interaction module are the basis of the presentation in Display module. As for 
Evaluation module, it is the mixture of Teacher module and Student module. Students' evaluation belongs to Student module, and teachers' evaluation belongs to Teacher module. On the whole, Teacher module is the guidance of Student module, however, Teacher module serves to Student module.

\section{Conclusion}

This article unscrambled the theory of ESP's creation and development at home and abroad, and elaborated the pivotal role of the ESP teaching theory in English teaching of 21st century. We have explored a set of classroom interaction based on ESP teaching in classroom settings with the help of pilot experiments teaching and the questionnaire. Seeing that ESP teaching is increasingly popular today, ESP teaching system derived in this article can solve two implements ESP teaching problems: first, the theory based on the proposed teaching curriculum for the professional needs of the students can stimulate students ' interest in learning, so as to improve their efficiency in English. Second, the interactive classroom model presented in this paper considered classroom student as class body, and teachers just lead the conversation, which to some extent solve the shortage of ESP teachers. We have reason to believe that this ESP teaching model will greatly make the promotion of ESP teaching in the University easier and play an important role on the teaching of ESP curriculum and implementation management.

\section{References}

[1] Alvarez, Brenda. Flipping the Classroom: Homework in Class, Lessons at Home [J]. Education Digest: Essential Readings Condensed for Quick Review, 2012.

[2] Cai Jigang, The influence of professional English and its teaching materials on ESP teaching in Chinese Universities [J]. College of foreign languages, Fudan University, 2003.

[3] Hutchinson T, Waters A. English for Specific Purpose: A Learning-centered Approach [M]. Cambridge: CUP, 1987:69-91.

[4] Li Hong, The development of ESP and the cooperative teaching of English Majors [J], foreign language teaching,2001,(1):21-22.

[5] Liu RunQing, English Teaching in twenty-first Century -- a survey of the United Kingdom [J], Foreign language teaching and research,1996.

[6] Qiao ShuXia. A study on the ESP curriculum of English majors from the perspective of Compound English talents cultivation [J], English Square,2013,57.

[7] Shu DingFang. Reform of foreign language teaching: Problems and Solutions. Shanghai foreign language education press [M],2004.

[8]Shu DingFang. The internationalization of higher education and the goal and orientation of College English Teaching [J]. Foreign Language Teaching and Research Press. 2011.

[9] Strevens P. ESP after twenty years: A re-appraisal. In M. Tickoo (ed.). ESP: State of the Art [C]. Singapore: SEAMEO RegionalLanguage Centre,1988.

[10] Wang YouLiang. A review of the study of English for special purposes (ESP) [J]. Journal of Central South University of Forestry and Technology,2008. 
[11] Xu Wei. A review of the research on demand analysis in foreign language teaching. ESP research in China [M].2012.

[12] Zhang LingHua, Zhao LingBiao. An empirical study on the integrated teaching model of multimedia and cooperative learning in ESP Curriculum $[\mathrm{J}]$. Education research and experiment,2008,69.

[13] Zhang YaoXue. Practical English teaching to improve the comprehensive ability of College Students [J]. Higher education in China,2002.

[14] Zhang ZhenBang. Problems of foreign language teaching reform in China [J]. Foreign language.2003. 